\title{
18TH CENTURY URBANIZATION IN SOUTH INDIA AND \\ TRANSFORMATION INTO BRITISH IMPERIAL ARCHITECTURE WITH SPECIAL FOCUS ON URBAN SPACES OF BANGALORE
}

\begin{abstract}
:
The colonial structures that still stand today in India are the product of careful fabrication of British thought. The British government was afraid of what kind of legacy they would leave behind when exiting India in 1947. Today, years after the independence of India, one is still able to see such a legacy in stone: the colonial architecture and cities that are still in existence. The styles of architecture employed by the British Raj were systematically chosen, dependent on the location and utilization of a given city. The British were trying to consecrate their power through architectural representation. Trying to legitimize British rule, architects wanted to tie the architecture of the British with former Indian rulers, yet still create an effect of British grandeur. The examples illustrate that location and utilization were indeed crucial determinants of colonial style.
\end{abstract}

V Anuradha

Department of History,

Maharani's Arts College for women,

Seshadri Road, Bangalore-560001, Karnataka, India.

Corresponding E-mail: anurakhal@gmail.com

\section{KEY WORDS:}

Urbanization, Tranformation of architecture, Imperial British architecture, Contonment, Military architecture, Bunglow

\section{Academic Discipline And Sub-Disciplines:}

Cultural Studies

SUBJECT CLASSIFICATION: History; Cultural studies

TYPE (METHOD/APPROACH): Historical field study of sites and appreciation of art forms.

\section{INTRODUCTION:}

\section{INTENTIONS OF THE BRITISH IN EARLY $18^{\text {TH }}$ CEN-PRESENTING A BRITISH IDENTITY THROUGH ARCHITECTURE}

British presence in India was focused in the major port cities that revolved around trade. Of these major areas include Madras, Calcutta, and Bombay. It is an incorrect assumption to state that no architecture was built in India during these early years of British presence; however, still one is able to see that the intentions for the architecture were drastically different when compared to those structures built under the formation of the British Raj. Structures and major planning was restricted to these areas, and were produced out of necessity as opposed to presenting a British ideal. This ideal Thomas Metcalf describes as including the national identity of the British. ${ }^{i}$ The British constructed an image of themselves during the eighteenth century that presented them as distinct, special, and superior to those colonial areas where they felt they had the right to rule. Buildings used for housing and trade posts were construed by them as little else was needed by the East India Trading Company to continue with their profitable pursuits. These structures, labeled 'factories', contained storehouses, barracks, a director's house, and other accommodations found necessary by the British ${ }^{\mathrm{ii}}$. In terms of stylistic preference, these first buildings were created more within European conventions of styles: classical, Greek, and gothic were of the major styles chosen ${ }^{i i i}$. British were in a hurry to build although little thought was given to the message that would be conveyed by these styles of architecture, still, using strictly European styles of architecture would present a group of people an identity in terms of racial, social and economic differences.

\section{BRITISH URBAN DESIGN POLICY}

The planning and urban design policies of the British followed certain principles -

(a) Their perceptions of the nature of the Indian city,

(b) The fear of further revolts along the lines of the Mutiny of 1857 ,

(c) Haussmann's plan for Paris which had become so popular in Europe and which advocated cutting through and demolishing old city centers to make space for new construction.

(d) Planning techniques already in use for Britain's industrial cities.

The British followed various architectural styles - Gothic, Imperial, Christian, English,

Renaissance, Victorian being the essentials. The architectural structures are basically 



\section{ISSN $2321-1091$ \\ Volume 10 Number 1 \\ Journal of Social Sciences Research}

Indian Christian art and architecture during the British Raj has expanded into several different styles as a result of extensive church building in different parts of the country. The style that was most patronized is generally referred to as the British Regency Style which included Gothic and Neo Gothic. Most Protestant cathedrals and churches in India conform to this style. ST Mary's church, Madras, the first Anglican Church built east of the Suez is one of the first examples of British colonial architecture in India. Local influence on Christian art and architecture in India can be seen today one can see a harmonious blending of the East and the West in the Christian art and architecture of India.

\section{PUBLIC STRUCTURES}

For the purposes of government buildings, something more assertive was needed to proclaim the supremacy of the British. It is thus that Government Houses and Town Halls, from where the business of governance and justice was carried out, follow closely changing trends in Britain to a great extent, and show also the continued influence of the so-called 'pattern books', from which the bulk of the Company's design was carried out. These pattern books, while conforming more or less to Europe's Greco-Roman heritage, incorporated ideas on the form architecture 'should' take, depending on its function. In essence, a pattern book would show how to put together different elements and combine them into a building. However, principles of urban design were applied here, stemming from its position in the last decades of the 18 th century as the hallmark of authority.

As the British consolidated their rule in Bangalore and their building needs grew, there was a debate as to which style of architecture should be followed. The final outcome was an amalgamation of architectural elements from both India and Europe. Within the colonial style of architecture there was difference between public buildings. While Public offices such as the Attara Katcheri were representations of colonial power, the residential buildings were designed bearing in mind the climatic conditions and the wishes of the residents to create houses that resembled their homes in Britain. This need was best satisfied by the 'Bungalow' type.

The Bungalow type, which developed in India and later spread to Australia and Africa, was derived from the detached rural Bengal house placed in a compound and the British suburban villa. The initial bungalows were same as the kutcha local ones but later became elaborate in design. From the basic plan of the main central room and the curvilinear thatching of the roof over, it got upgraded to the sloping titled roof and the verandah and side rooms. The elementary plan of the bungalow was the porch, the verandah, the drawing and dining rooms with bedrooms on the sides and the service annexes in the rear yard. The building was situated in the middle of a compound, which had a garden of roses, fernery etc which were psychological references to British homes.

The architectural style of bungalows went through 2 distinct phases namely the earlier classical phase and the later gothic phase. This was unlike public architecture in which the gothic phase was followed by the classical phase. Long low classical lines and details characterized the early phase of bungalows, while later the bungalows had an additional floor with multi-planned gabled roofs and monkey tops with a profusion of ornamentation. In Bangalore, bungalows played a role in establishing social and psychological boundaries between the British and the Indians. The tall imposing gates and the long drive to the porch and the spacious verandah leading to the drawing room, which were the ideals of a residential building, were also symbols of the insularity of the residents from the 'natives'. The features of a Bungalow such as thick walls and high ceilings were on one hand adaptations to the Indian weather while on the other hand acted as a boundary from the locals. Similarly the inner courtyard of a traditional Indian house was replaced by the hall, which helped in segregating the servants from the family members. The amount of land used for the bungalow was also socially dictated. For example for a senior officer the area of the garden would be fifteen times the size of the house, while for a low ranking officer it might be a ration of $1: 1$.

Therefore the Bungalow and the space it occupied became a tool to not only assert the social and cultural superiority of the British over the Indians, but also to establish a hierarchy between the British officials. In other words, the Bungalow was an architectural entity shaped by an ideology

of hierarchy, power and control.

\section{ROYAL ARCHITECTURE}

The Lalitha Mahal Palace was built in 1921 by E.W. Fritchley under the commission of Maharaja Krishnaraja IV. The architectural style is called "Renaissance" and exhibits concepts from English Manor houses and Italian palazzos. The central dome is believed to be modelled on St Paul' Cathedral in London. Other important features are the Italian marble staircase, the polished wooden flooring in the banquet and dance halls, and the Belgian cut glass lamps. The Jaganmohana Palace was commissioned in 1861 and was completed in 1910. The three-storeyed building with attractive domes, finials and Cupolas was the venue of many a royal celebration. It is now called the Chamarajendra Art Gallery and houses a rich collection of artifacts.

\section{CONTRIBUTION OF GERMAN ARCHITECTS}

During World War II, Germans in India were declared as enemies and Krumbiegel was along with other Germans kept in an internment camp in Bangalore! Vandana goes on to say in her thesis that the Mysore Government negotiated with the British Resident in Mysore to retain Krumbiegel, Exener, and Koenigsberger (all German architects) as government architects during World War II, during which the German architects were classified as enemy subjects and confined to the 


\section{ISSN $2321-1091$ \\ Volume $10 \mathrm{Number} 1$ \\ Journal of Social Sciences Research}

camp. The Mysore Durbar (court) exercised considerable pressure on the British residency for their immediate release so that they could continue working on architectural designs ${ }^{\mathrm{vi}}$.

The design of the town and city involves the meticulous hand of the Master planner who must be both an artist and a technician. A qualified town planner does not necessarily make a good town designer. He may have a lot of ideas and sound theories to put into practice but he will need the sensitivity of the artist to make his planning concept emerge as a praiseworthy physical entity. The beautiful city is a visual experience which requires concerted efforts to reconcile the intrinsic quality of the terrain onto the two-dimensional plan that take into considerations breathtaking vistas. Exquisite natural vegetations and other element of surprises that can put the beholder into a state of awe. It is also widely believed that Mother Earth has an inborn spirituality that guides its future destiny governed by her relationship with the Cosmos. The 'genii loci' which means the spirit of the place in Latin will inevitably determine the future success or otherwise of the city based on its original sitting.

\section{Foot notes:}

' Metcalf, Thomas R. Ideologies of the Raj. Cambridge: Cambridge University Press, 1994: 3,page-42

ii The earliest of these factories dates 1611, built in northern Madras.

iii Specifically gothic was a style most favored in Bombay.

iv Stephen Andrew Missick. "Mar Thoma : The Apostolic Foundation of the Assyrian Church and The Christians of St Thomas in India"Journal of Assyrian academic studies.Page-14

${ }^{v}$ Origin of Christianity in India - A Historiographical Critique by Dr. Benedict Vadakkekara. (2007). ISBN81-7495-258-6

vi Vandana Baweja in her Ph.D. thesis, A Pre-history of Green Architecture: Otto Koenigsberger and Tropical Architecture, from Princely Mysore to Post-colonial London, 2008,

Bertraud, A. (2002), The Spatial Organization of Cities, World Development Report Background Paper, The World Bank, Washington DC.

\section{References}

1. Indo-Saracenic Architecture-Henry Irwin, Architect in India, 1841-1922.higman,de.

2. Metcalfe, Thomas R. -A Tradition created: Indo-Saracenic Architecture under the Raj-. History Today 32 (9). Retrieved 14 Sep 2012.

3. Rao, Velcheru Narayana, David Shulmanand Sanjay Subrahmanyam, Textures of Time: Writing History in South India1600-1800(2003).

4. Colonial Urban Development: Culture, Social power and Environment by Anthony King.

5. European Architecture in India $-1750-1850$ by Sten Nilsson.

\section{Author Biography with Photo}

I Dr. Anuradha V working as Associate Professor in Department of History, Maharani's Arts College for women, Seshadri Road, Bangalore-560001, Karnataka, India. I have more than 22 years of teaching and 10 years of research experience. I have completed my graduation and post-graduation from Bangalore University. I have worked on Development of temples of Bangalore on Art and Architecture for my M.Phil degree from Bangalore University and secured Ist rank. My Ph.D. degree was awarded from University of Mysore on the title Development of temple architecture in Southern Karnataka (with special reference to Kolar and Bangalore). I have presented research papers and published more than 50 articles in national and International seminars and conferences. I have visited different countries viz., Thailand, Nepal, Sri Lanka etc to study the art and architecture. I have delivered various talks in different parts of India and abroad on the culture, art and architecture and sculpture. 